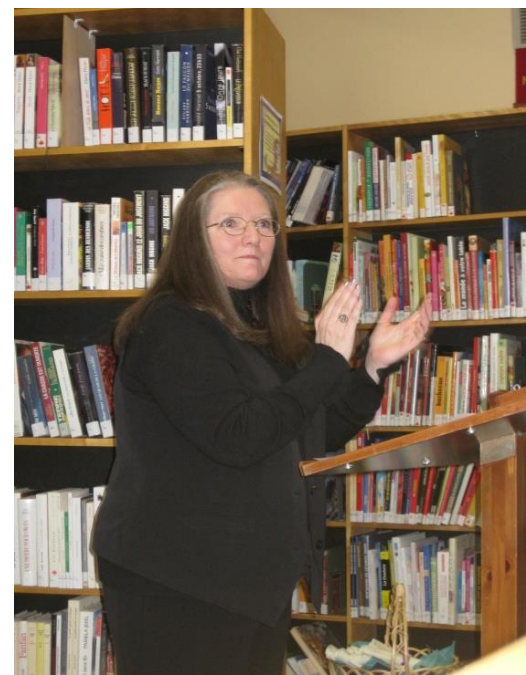

\title{
Profile: Jocelyn Paquette
}

Directrice de bibliothèque / Library Director Bibliothèque du centenaire de Campbellton / Campbellton Centennial Library Campbellton, New Brunswick

Picture it: 1963 Ottawa. A hush of silence hung in the still air. Well maybe not so much. With four sisters, three brothers and parents, this fairytale vision has never been a reality of mine. What does remain with me as I celebrate my $60^{\text {th }}$ is the sense of urgency when something must be done. Partnership development is like that. Identify what needs are to be met and find those able to assist in accomplishing the goal. No matter where you are.

I began my role as Library Director of the Campbellton Centennial Library on September $11^{\text {th }}, 2006$. The very day reminded me of our fragility. The economic downturn had begun to be reflected in our patrons' faces, in our emptying stores and in the lack of employment. If, in my mind's eye, Ottawa was a village then Campbellton was - to this "come from away" - the Metropolis of northern New Brunswick.

My first step was finding Community Partners who could make funds flow in our direction. Validating the important contribution made by our patrons was a new concept to many. A no-nonsense approach that stated the exact amount or item required by the team soon realized resources for our programs. Visibility for the local businesses added depth and worth to our Activities Pamphlet. Know your audience: at least, that was what Florenz Ziegfeld believed. The Follies were the embodiment of the times - the pulse of the nation. In our libraries this feeling of capturing the wave of our clients is core to meeting their needs and challenging ourselves to provide services that matter. If I were to express gratitude to only one partner it would be our schools. They were the entry point: the content-defining and results-oriented entities in our environment. Ask a teacher what would help, and they are quick to reply. Then give them that thing and you create a relationship that endures. Art, history, science and literature all served as backdrops to our programming with the local schools; Lord Beaverbrook Elementary, Campbellton Middle, Tide Head, École Apollo-XI, Polyvalent Roland-Pépin and Sugarloaf Senior High have made us proud to be part of the community.

There you have it in a nutshell: success is what you believe in. It was my honor to be a recipient of the Queen Elizabeth II Diamond Jubilee Medal this year, and it truly felt like a community event. Amongst my patrons, colleagues and community leaders I felt truly blessed.

Librarianship begins in Development. 